Bręborowicz E., Lubiatowski P., Olczak I., Bręborowicz M., Redman M., Romanowski L. Evaluation of elbow joint position sense with electronic goniometer - new methodology and pilot study. Issue Rehabil. Orthop. Neurophysiol. Sport Promot. 2017; 19: 16-26. DOI: 10.19271/ IRONS-00039-2017-19

\section{EVALUATION OF ELBOW JOINT POSITION SENSE WITH ELECTRONIC GONIOMETER - NEW METHODOLOGY AND PILOT STUDY}

\section{Ewa Bręborowicz}

Przemysław Lubiatowski

Izabela Olczak

Maciej Bręborowicz

Marcin Redman

Leszek Romanowski

Department of Traumatology, Orthopedics and Hand Surgery, Poznan University of Medical Sciences

\section{SUMMARY}

\section{Introduction}

Proprioception of the elbow is not so extensively studied as the knee and shoulder. In order to obtain more comprehensive information about the elbow we need to develop a protocol of passive and active proprioception evaluation.

\section{Aim}

The aim of the study was to develop a protocol of an active and passive elbow joint position sense measurement, using electronic goniometer idea (Propriometer) and check new methodology with healthy group.

\section{Material and methods}

A pilot study was carried out on a control group of 21 healthy subjects with the average age of 26. Three references positions were tested.

\section{Results}

The cumulative results of average error of passive reproduction of the joint position had ranged between $2.8^{\circ}-4.6^{\circ}$. Average error of active reproduction of the joint
BADANIE PROPRIOCEPCJI STAWU ŁOKCIOWEGO Z UŻYCIEM GONIOMETRU ELEKTRONICZNEGO - NOWA METODYKA I BADANIE PILOTAŻOWE

Ewa Bręborowicz

Przemysław Lubiatowski

Izabela Olczak

Maciej Bręborowicz

Marcin Redman

Leszek Romanowski

Katedra i Klinika Traumatologii, Ortopedii i Chirurgii Ręki, Uniwersytet Medyczny w Poznaniu

\section{STRESZCZENIE}

\section{Wstęp}

Propriocepcja stawu łokciowego nie jest obiektem tak intensywnych badań jak stawu kolanowego czy ramiennego. Aby uzyskać wszechstronne dane odnośnie stawu łokciowego niezbędne jest stworzenie protokołu biernego i czynnego badania propriocepcji.

\section{Cel}

Celem badania było stworzenie protokołu biernego i czynnego badania czucia pozycji stawu łokciowego przy użyciu goniometru elektronicznego (Propriometr) oraz ewaluacja nowej metodyki na grupie zdrowych osób.

\section{Materiał i metody}

Pilotażowym badaniem propriocepcji stawu łokciowego objęto 21 zdrowych osób (średnia wieku 26 lat). Zbadane zostały trzy pozycje stawu łokciowego.

\section{Wyniki}

Zakres błędu odtworzenia pozycji stawu w badaniu biernym wynosił pomiędzy $2,8^{\circ}$ a $4,6^{\circ} \mathrm{W}$ badaniu czynnym $2^{\circ}-4,3^{\circ}$. Wykazano lepszą kontrolę stawu $\mathrm{w}$ pozycjach 
position was between $2^{\circ}-4.3^{\circ}$. The results have shown better elbow joint control in a position of flexion than the extension positions, especially in active motions.

\section{Conclusion}

Methodology and devises have allowed an objective examination of both passive and active elbow joint position sense.

Key words: elbow, joint position sense, proprioception, methodology, electronic goniometer

Date received: 3rd April 2017

Date accepted: 9th May 2017

\section{Introduction}

Proprioception is one of the most investigated neuromuscular abilities. It had been described for the first time by Sherington at the beginning of the last century (Sherrington 1906). He had introduced, and defined, the term proprioception. The novel definition describes proprioception as the ability of an individual to determine body segment positions and movements in space. In this concept, sensory signals are provided from muscles, joints and skin receptors to the brain (Goble 2010; Goble et al. 2010). Two of the main tasks of proprioception in the motor control system, include motor reflex and control. The first, is immediate reaction to unexpected disruption in an external habitat. The second, is internal motor control of current and changing positions (Riemann et al. 2002).

Proprioception is composed of four different senses: a sense of position and movement, a sense of tension, a sense of balance and a sense of effort (Proske 2005). The most common proprioceptive abilities are evaluated by the measurement of joint position sense. Proprioception of the knee and shoulder has been extensively studied, but the sense of position and movement of the elbow has been much less explored. zgięcia niż wyprostu, szczególnie w badaniu czynnym.

\section{Wnioski}

Opracowana metodyka i sprzęt pozwala na obiektywne zbadanie czucia pozycji stawu łokciowego zarówno w protokole czynnym jak i biernym.

Słowa kluczowe: staw łokciowy, czucie pozycji stawu, propriocepcja, metodyka, goniometr elektroniczny

Data otrzymania:3 kwietnia 2017

Data zaakceptowania: 9 maja 2017

It is debatable how the proprioception of any joint, and non-weight bearing joints like the elbow, should be approached. Passive reproduction of the joint position would allow for the evaluation of purely afferent pathways (sensation), whereas active repositioning would reflect both reflex - afferent (sensation) and efferent (motor control) pathways. Most studies focus on one of these methods. In order to obtain more comprehensive information we have developed both active and passive modes of proprioception evaluation.

\section{Aim}

The aim of the study was to develop a protocol of an active and passive elbow joint position sense measurement with the use of a specific PC controlled electronic goniometer.

\section{Material and methods}

The study group had included 21 healthy volunteers (14 men and 7 women) with the average age of 26 (20-30 y.o.), without any elbow and/or neurological problems.

Complete measurement of proprioceptive abilities consisted of active reproduction of the joint position (ARJP) and passive 
reproduction of the joint position (PRJP) with the use of an electronic goniometer (Priopriometer). Both dominant and non-dominant side were evaluated.

\section{Propriometer}

We have developed a device - an electronic goniometer with the accuracy of $0.1 \mathrm{deg}-$ Propriometer (Progres, Poland). The set is composed of a transducer with accelerometer (based on the Earth magnetic field), a PC panel and a PC computer with dedicated software (Lubiatowski et al. 2013) This device is universal and can be applied to any joint with axial movement. We have used it for shoulder proprioception evaluation (Lubiatowski et al. 2013; Ogrodowicz 2010; Roga et al. 2014) Propriometer was positively validated (results were published during international hand surgery congress).

\section{Measurement set-up}

The Biodex system had been used to provide a stable whole body position and support undisturbed movement of the elbow. The examinee had been seated in a Biodex chair. His or her arm had been fixed to the support frame, with an unfettered elbow. The arm was positioned in $90^{\circ}$ in scapular plane, the elbow was in $90^{\circ}$ of flexion, the forearm was in neutral position. This position had been used for both active and passive evaluation. Additionally, for passive evaluation, the patient had held the Biodex moving arm, which allowed the patients' elbow to undergo continuous passive motion with constant speed of $2^{\circ} \mathrm{s}$. We had used the passive bilateral Biodex protocol. The transducer had been placed parallel to the forearm, on the Biodex moving arm (Figure 1).

For active evaluation, patients' forearms was free. The transducer had been placed on the examined person's forearm (Figure 2).

For both protocols, the examined person's eyes had been covered, and he/she had been holding the remote in the non-examined hand. The room was silent.

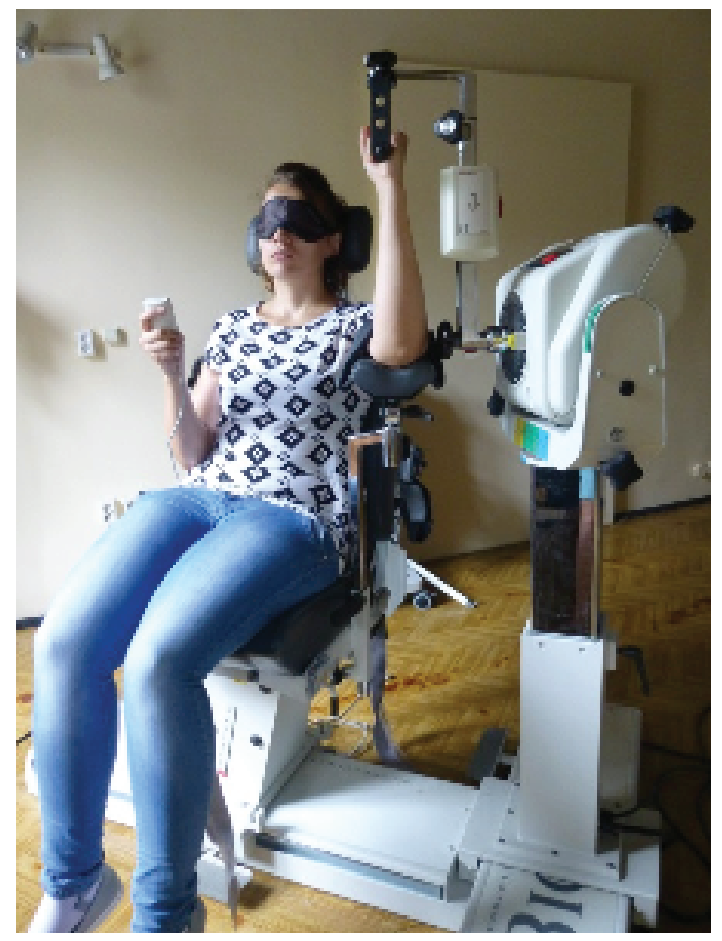

Figure 1. Elbow joint position sense measurement (passive mode) - examinee holds the Biodex moving arm which allows the elbow to be in continuous passive motion, the transducer is placed parallel to the forearm, on the Biodex moving arm; the examinee holds the remote in the contralateral hand.

\section{Join position sense examination}

The starting position for all measurements was $90^{\circ}$ of elbow flexion with the forearm perpendicular to the floor. Then, depending on the measurement, the examinee's forearm was positioned to the one of reference positions (flexion to $110^{\circ}$, extension to $50^{\circ}$ or $70^{\circ}$ ). The reference positions were presented actively with examiners' assistance (in active evaluation) or with the Biodex moving arm (in passive evaluation). The examinee would then memorize the position, and confirm it, by pressing the remote button. Thus, the exact value of the angle had been recorded. Next, the forearm was returned to the starting position. The examined person was asked to reproduce the reference position and press the button again to confirm. The reproduced angle was automatically recorded in the database. Finally, the error of reproduction of the joint position (ERJP) was calculated, 

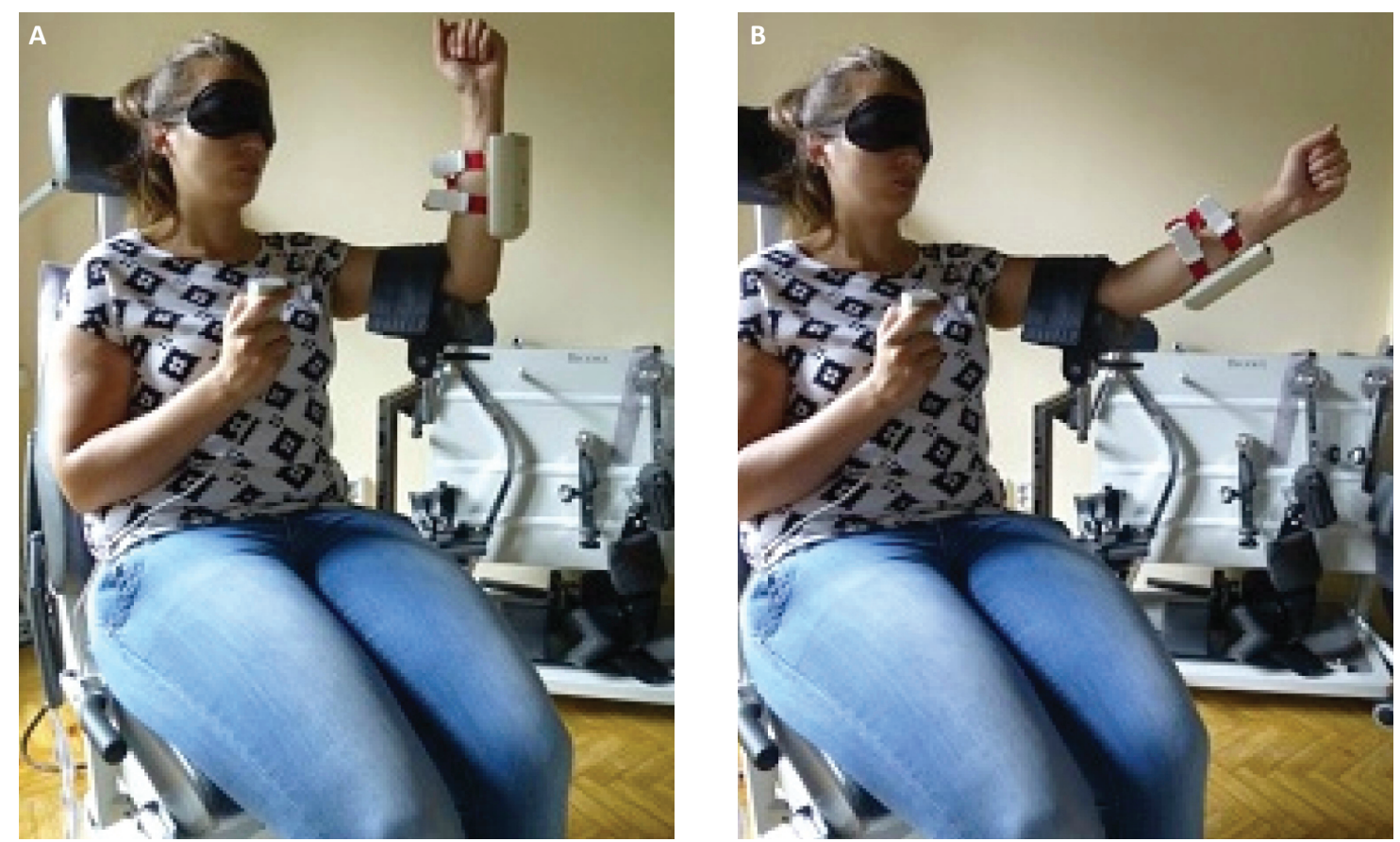

Figure 2. Elbow joint position sense measurement (active evaluation) - examiner's arm is fixed into the support frame, the forearm is free, the transducer is placed on the examined person's forearm; the examinee holds the remote in the contralateral hand. A. Starting position, B. Reference position.

as a difference between absolute values of reference, and reproduced angles. For the passive protocol, the angles and positions would be confirmed while the elbow was moving passively by a Biodex frame, and when the forearm had achieved the desired position passing by. In the active protocol, the patient had been using his or her muscles to move the forearm to the indicated position and then stopped. Algorithm of active and passive elbow proprioception measurement illustrate Figure 3.

There had been three repetitions for every position for both active and passive evaluation. An average of three was calculated to get the final result - an average error for each active (EARJP) and passive (EPRJP) reproduction of the joint position.

\section{Statistical analysis}

StatPlus Mac 2009 software (AnalystSoft) had been used for statistical analysis. Normality tests had been performed. Depending on the distribution and data, t-student, ANOVA and Mann-Whitney tests had been utilized. 


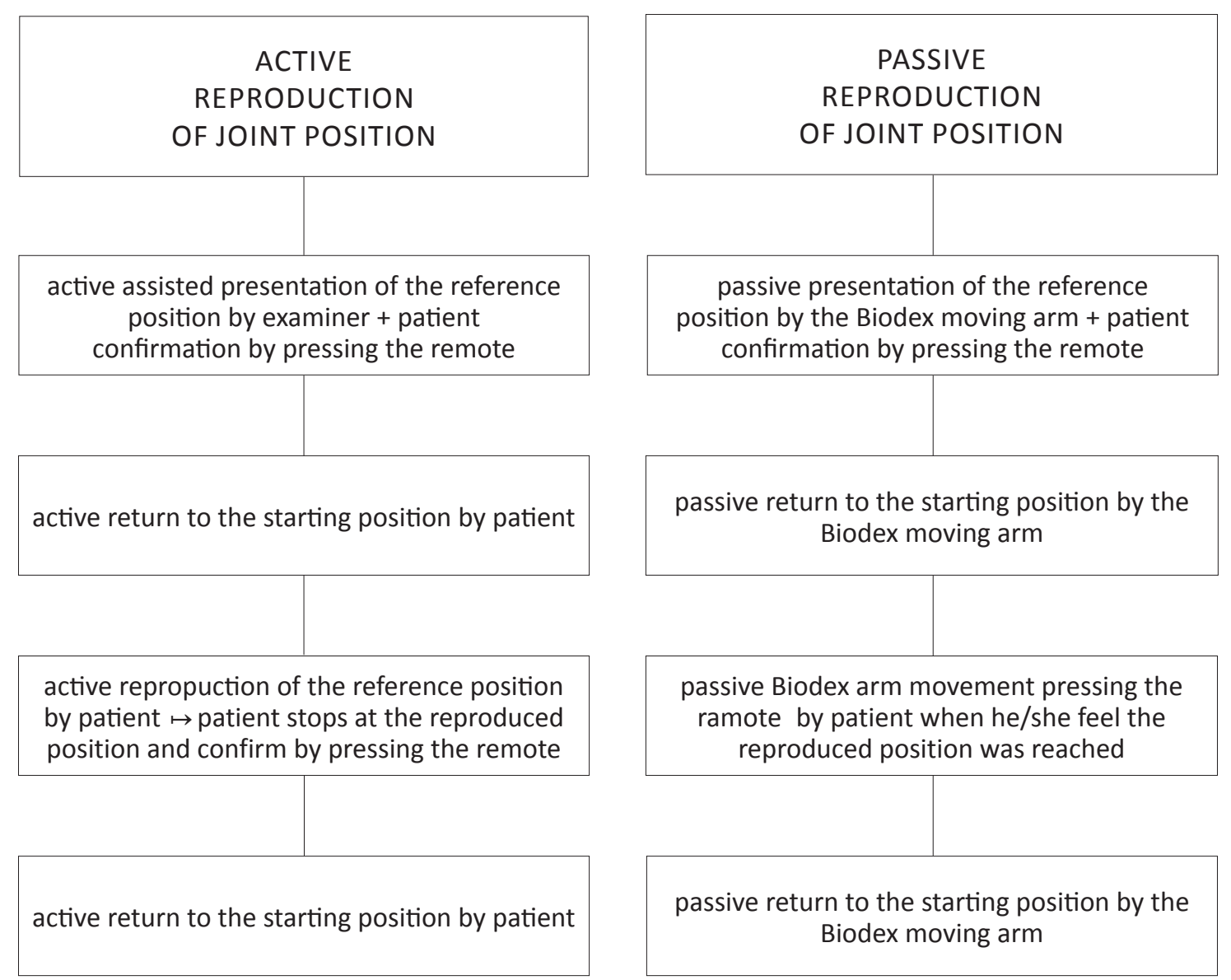

Figure 3. Algorithm of active and passive elbow proprioception measurement.

\section{Results}

Detailed results for EARJP and EPRJP for the dominant and non-dominant elbow, as well as cumulative data (dominant + non-dominant), have been summarized in Figure 4 - Figure 6.

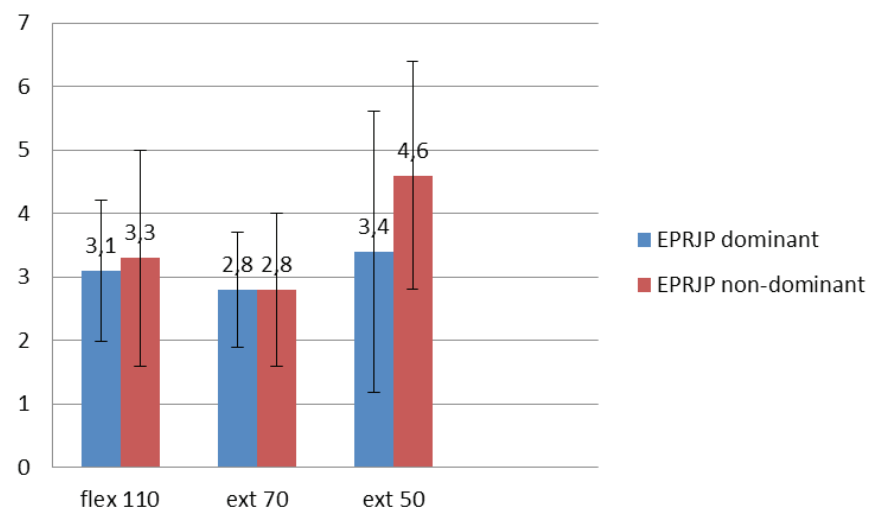

Figure 4. Average error of passive reproduction of the joint position (EPRJP) sense for the dominant and non-dominant side at three reference positions (flex 110 -flexion to reference angle of $110^{\circ}$, ext 70 -extension to reference angle of $70^{\circ}$, ext 50 -extension to reference angle of $50^{\circ}$ ). 


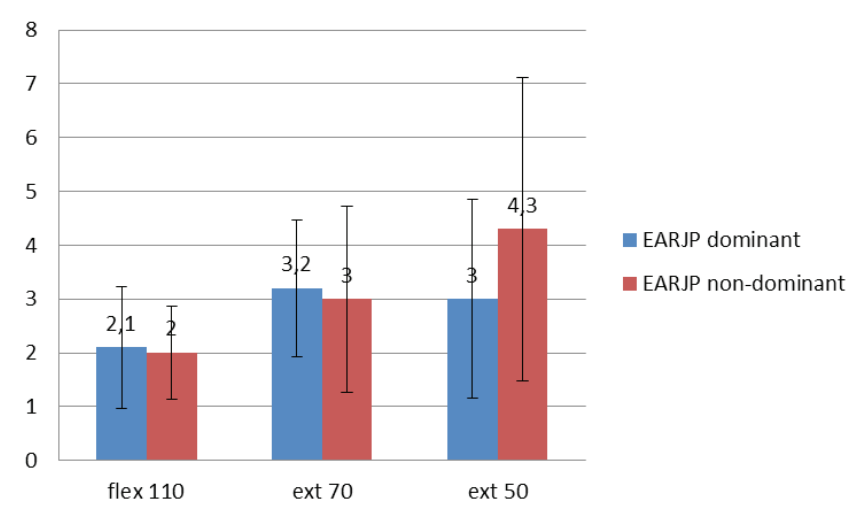

Figure 5. Average error of active reproduction of the joint position (EARJP) sense for the dominant and non-dominant side at three reference positions (flex 110 -flexion to reference angle of $100^{\circ}$, ext 70 -extension to reference angle of $70^{\circ}$, ext 50 -extension to reference angle of $50^{\circ}$ ).

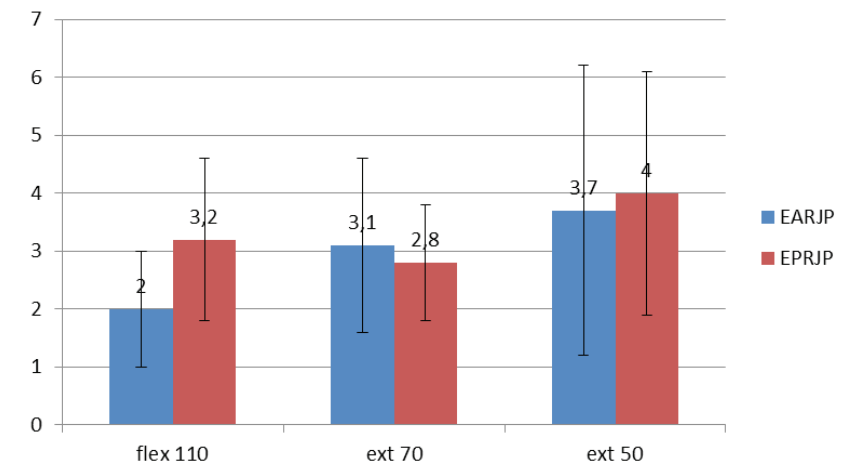

Figure 6. Cumulative values (dominant + non-dominant) of the average error of active or passive reproduction of the joint position (flex110-flexion to reference angle of $100^{\circ}$, ext 70-extension to reference angle of $70^{\circ}$, ext 50 -extension to reference angle of $50^{\circ}$ ).

Average error values in general ranged from $2^{\circ}-4.6^{\circ}$. No significant differences of joint position reproduction had been found when dominant and non-dominant limbs were compared. Any dependence of error on elbow deviation from the starting position had been looked into. Acuity in reproducing $110^{\circ}$ flexion was significantly higher than for $50^{\circ}$ extension for active and passive (only non-dominant) evaluation (Table 1). 
Table 1. Analysis of difference between positions in the ANOVA test, NS-non significant.

\begin{tabular}{|c|c|c|}
\hline Mode of JPS measurement & Analysis of variance & p-level \\
\hline \multirow{3}{*}{$\begin{array}{l}\text { passive evaluation } \\
\text { dominant side }\end{array}$} & $110^{\circ}$ flexion vs. $50^{\circ}$ extension & NS \\
\hline & 110 flexion vs. 70 extension & NS \\
\hline & 50 extension vs. 70 extension & NS \\
\hline \multirow{3}{*}{$\begin{array}{l}\text { passive evaluation } \\
\text { non-dominant side }\end{array}$} & 110 flexion vs. 50 extension & 0,01 \\
\hline & 110 flexion vs. 70 extension & NS \\
\hline & 50 extension vs. 70 extension & $<0.001$ \\
\hline \multirow{3}{*}{$\begin{array}{l}\text { active evaluation } \\
\text { dominant side }\end{array}$} & 110 flexion vs. 50 extension & 0.05 \\
\hline & 110 flexion vs. 70 extension & $<0.02$ \\
\hline & 50 extension vs. 70 extension & NS \\
\hline \multirow{3}{*}{$\begin{array}{l}\text { active evaluation } \\
\text { non-dominant side }\end{array}$} & 110 flexion vs. 50 extension & 0.0003 \\
\hline & 110 flexion vs. 70 extension & NS \\
\hline & 50 extension vs. 70 extension & $<0.04$ \\
\hline
\end{tabular}

Joint position sense in extension $70^{\circ}$ was significantly better than $50^{\circ}$ extension for both passive and active evaluation for the non-dominant side (Table 1). We have also analysed passive versus active abilities in elbow position acuity. We had found out that active flexion was more precise than passive for cumulative dominant and non-dominant elbow data (Figure 6, Table 2).

Table 2. Comparison of active and passive reproduction of the joint position at three angles (cumulative data for dominant and non-dominant side).

\begin{tabular}{llll} 
position & active & passive & p-value \\
\hline flex 110 & 2 & 3.2 & 0.00007 \\
\hline ext 70 & 3.1 & 2.8 & NS \\
\hline ext 50 & 3.7 & 4 & NS
\end{tabular}

\section{Discussion}

One of the most important roles of proprioception, is to maintain global (postural) and segmental stabilization (of each joint) (Riemann et al. 2002). For the upper limb, motion control in an open kinematic chain plays a crucial role, therefore, in order to examine elbow proprioception we have chosen joint position sense (JPS) testing. In literature, few studies could be found on the elbow proprioception (Haavik et al. 2011;

Hattori et al. 2009; Juul-Kristensen et al. 2008; Juul-Kristensen et al. 2008; Khabie et al. 1998; Manske et al. 2010; Özkul et al.
2012). Based on our own research, on glenohumeral joint position sense (Ogrodowicz 2010; Roga et al. 2014), and on literature, we have developed our own protocol for testing the elbow. We had assumed, that for a greater chance of detecting control disorders, we should examine both the sensory and motor components, taking into account both perception and the muscle control. Movement should be predictable and repeatable, with maximum possible exception of the need to stabilize other parts of the body (trunk, shoulder, hand) and visual control. Measurement accuracy should reach $\sim 0,1^{\circ}$. Therefore, we had relied the research methodology on a combination of high accuracy of electronic goniometer and Biodex System 4 Pro (for motion stability and propelling constant passive motion). The use of an electronic goniometer is a standard procedure in joint position sense testing (Haavik et al. 2011; Hattori et al. 2009; Juul-Kristensen et al. 2008; Khabie et al. 1998; Manske et al. 2010). It provides greater accuracy than the manual goniometer examination. So far, devices simultaneously placed on the patient's arm and forearm, had been used in all of such studies. Those devices had contained three markers that had provided data on the position of the arm and forearm. Then, the angle had been calculated 
on that basis (Haavik et al. 2011; Hattori et al. 2009; Juul-Kristensen et al. 2008; Khabie et al. 1998; Manske et al. 2010).

According to our observations, application of the markers on the skin, in several places, might facilitate the patient to find the reference position by activating more of the receptors in the skin. Our device consists of one element attached only to the forearm. This is possible due to the accelerometer, which records the position in relation to Earth's magnetic field. By eliminating the two points of application of the device, we have reduced the ability to feel the joint position, and thus, objectified the study. In order to obtain a uniform motion with a constant angular velocity, we had used a movable frame from Biodex 4 Pro System. Similar use of the Biodex System can be found in the work of Khabie and co-authors (Khabie et al. 1998). We had used the passive bilateral protocol, where in the movement speed was $2^{\circ} / \mathrm{sec}$. An additional advantage of the Biodex System, is a chair with an arm support which provides a stable position of the examined person. It had been used during both the active and the passive part of the study. This was created in order to exclude the influence of any postural disturbances on our results. Unstable or unsupported elbow motion reflects the information not only from elbow receptors but also activate the shoulder muscles (Talis et al. 2011). Ozkul and co-authors, have shown that the error of reproduction of the elbow joint position, with visual control, is significantly lower than the error without it (Özkul et al. 2012).

In order to eliminate visual control during our study, the volunteers had been blindfolded, which is found to be done in most studies of proprioception. A high accuracy of measurement is necessary for precise determination of the position, and its exact angle. Most papers do not include the system of accuracy of measurement. The only exception is the study by Brady at al. They have used an electromagnetic tracking device with the accuracy of $0.5^{\circ}$ (Tripp et al. 2009). Our goniometer measures the angle with the accuracy of 0.1 degree. Most researchers in their have recommended the patients to stop motion and for 3-5 seconds to keep the reference/ reproduced position (Haavik et al. 2011; Hattori et al. 2009; Juul-Kristensen et al. 2008) in their methodology. In Khabie's and co-authors' study, in order to determine the reproduced position, the button stopping the motion on the Biodex device had been used, while the reference position had been stopped for 2 seconds for better memorization (Khabie et al. 1998). Similarly, in the publications by Juul-Kristensen and co-authors, people had marked only the reproduced position in passive study (Juul-Kristensen et al. 2008; Juul-Kristensen et al. 2008). We had used the remote control, which served for saving both the reference and the reproduced position by the patient. This seems to improve accuracy of recording the achieved position parameters, by avoiding the change of the joint angle that might occur when no immediate recording is possible. Most studies (Hattori et al. 2009; Juul-Kristensen et al. 2008; Manske et al. 2010; Özkul et al. 2012), as well as ours, had been carried out in the sitting position. For an initial position, researchers have chosen full extension (Hattori et al. 2009; Juul-Kristensen et al. 2008; Manske et al. 2010; Özkul et al. 2012). We have adopted a methodology similar to Haavik and co-authors, and have considered the initial position of 90 degrees, as it is the resting position of the glenohumeral-elbow joint, where the articular capsule and ligaments are relaxed. Furthermore, both active and passive flexion and extention movements are possible from that position. In most of the studies, specific initial and reference positions were determined (Hattori et al. 2009; Juul-Kristensen et al. 2008; Manske et al. 2010; Özkul et al. 2012). Only in one work by Haavik and co-author, the initial and reference positions had always been chosen randomly, but being within a certain 
division of range of motion (Juul-Kristensen et al. 2008). Our choice was to establish an initial position of $90^{\circ}$, and the reference positions $-50^{\circ}, 70^{\circ}$ and $110^{\circ}$. In order to verify our methodology, we had examined 21 healthy volunteers. The average results in literature have ranged between 2.7 and 5.6 ${ }^{\circ}$ Haavik et al. 2011; Hattori et al. 2009; Juul-Kristensen et al. 2008; Khabie et al. 1998; Özkul et al. 2012). Our results are most similar to the Khabie's and co-authors' research, in which the average error was $3.3^{\circ}$, and in which also the Biodex System and electronic goniometer had been used. Our results had ranged between 2.6 and 4.2 degrees, in the passive study, and between 2 and 3.3 degrees in the active study. In our study we did not find a significant difference between the dominant and the non-dominant limb. For the dominant limb the average error was $3.1^{\circ}$ in the passive study, and $2.7^{\circ}$ in the active study. For the non-dominant: respectively $3.5^{\circ}$ and $3.1^{\circ}$. Researchers who have compared the error of reproduction between the dominant and non-dominant hand on healthy subjects had also found no significant difference between the parties (Juul-Kristensen et al. 2008; Khabie et al. 1998). However, we have noted the dependence of accuracy of matching the position according to motion (flexion, extension) and the reference angle. In the study group, the lowest accuracy had been demonstrated in the position of extension $50^{\circ}$ - both active and passive (Table 1). This had been unexpected, since as we have learned from our shoulder studies, where larger deviation the better sensation (Lubiatowski et al. 2013; Ogrodowicz 2010). In contrast, the best-matching position was active flexion in $110^{\circ}$. On this basis, we suppose that smaller errors of reproduction of the position had been obtained in flexion, than extension, especially in active motions. This may prove that the elbow flexion motions are more controlled than extension motions. It is possible that the other control mechanisms (the active effect of gravity, muscles) also take part in it. Presumably, active control and muscle function are essential for motion control. Gandevia had already drawn attention to this in 1975 (Gandevia et al. 1976). He had stated, that the afferent information from contracting muscle is responsible for the joint position sense, especially in active control of the joint.

Our study, has shown better control of active than passive reproduction, both in the dominant hand, as well as the opposite one. Proprioception studies have been recognized in clinical disorders. Elbow proprioception has been studied in conditions such as: brachial plexus injury, tennis elbow (Hattori et al. 2009; Juul-Kristensen et al. 2008)

Elbow proprioception still leaves a lot to be discovered. We believe that our device will deepen this knowledge, e. g. through the adoption of precise and reproducible methodology of the research.

\section{Conclusions}

The research has enabled the development of a precise methodology to evaluate the elbow joint proprioception, using our own electronic goniometer idea (Propriometer) and Biodex System. Methodology and devices have allowed an objective examination of both passive and active elbow joint position sense.

The cumulative results of average error of passive reproduction of the joint position had ranged between $2.8^{\circ}-4.6^{\circ}$. Average error of active reproduction of the joint position was between $2^{\circ}-4.3^{\circ}$. Limb preference did not affect the accuracy in the reproduction of the elbow joint position. The results of the study on the group of healthy subjects have shown better elbow joint control in a position of flexion than the extension positions, especially in active motions. Active joint control had been better in extreme positions and passive joint control - closer to the middle of range of motion. 


\section{REFERENCES}

Gandevia, S.C., McCloskey, D.I. (1976) „Joint sense, muscle sense, and their combination as position sense, measured at the distal interphalangeal joint of the middle finger". J Physiol. 260(2), pp. 387-407. Goble, D.J. (2010) „Proprioceptive acuity assessment via joint position matching: from basic science to general practice" Phys Ther. 90, pp. 1176-1184.

Goble, D.J., Nobleb, B.S., Brown, S.H. (2010) „Where was my arm again? Memory-based matching of proprioceptivee targets is enhanced by increased target presentation time". Neurosci Lett 481, pp. 54-58.

Haavik, H., Murphy, B. (2011) „Subclinical neck pain and the effects of cervical manipulation on elbow joint position sense". J Manipulative Physiol Ther. 34(2), pp. 88-97. Hattori, Y., Doi, K., Sakamoto, S., Yukata, K., Shafi, M. (2009) „Elbow joint position sense following brachial plexus palsy treated with double free muscle transfer". J Hand Surg Am. 34, pp. 1667-1673.

Juul-Kristensen, B., Lund, H., Hansen, K., Christensen, H., Danneskiold-Samsøe, B., Bliddal, H. (2008) „Poorer elbow proprioception in patients with lateral epicondylitis than in healthy controls: A cross-sectional study". J Shoulder Elbow Surg. 17, pp. 72S-81S.

Juul-Kristensen, B., Lund, H., Hansen, K., Christensen, H., Danneskiold-Samsøe, B., Bliddal, H. (2008) „Test-retest reliability of joint position and kinesthetic sense in the elbow of healthy subjects". Physiother Theory Pract. 24(1), pp. 65-72.

Khabie, V., Schwartz, M.C., Rokito, A.S., Gallagher, M.A., Cuomo, F., Zuckerman, J.D. (1998) „The effect of intraarticular anesthesia and elastic bandage on elbow proprioception". J Shoulder Elbow Surg. 7, pp. 501-504.

Lubiatowski, P., Ogrodowicz, P., Wojtaszek, M., Kaniewski, R., Stefaniak, J., Dudziński, W., Romanowski, L. (2013) „Measurement of active shoulder proprioception: dedicated system and device".
Eur J Orthop Surg Traumatol. 23(2), pp. 177-183.

Manske, R., Stovak, M., Cox, K., Smith, B. (2010) „Elbow joint active replication in college pitchers following simulated game throwing: an exploratory study". Sports Health. 2(4), pp. 345-350.

Ogrodowicz P. (2010) „Effect of unilateral traumatic, recurrent, anterior instability of the shoulder on dynamic proprioception disorder, expressed as an error of active reproduction of joint position sense". doctoral thesis, University of Medical Sciences, Poznań

Özkul, F., Erol Barkana, D., Badıllı Demirbas, S., Inal, S. (2012) „Evaluation of elbow joint proprioception with RehabRoby: a pilot study". Acta Orthop Traumatol Turc 46(5), pp. 332-338.

Proske, U. (2005) „What is the role of muscle receptors in proprioception?" Muscle Nerve 31, pp. 780-787.

Riemann, B.L., Lephart, S.M. (2002) „The Sensorimotor System, Part II: The Role of Proprioception in Motor Control and Functional Joint Stability". J Athl Train. 37(1), 80-84.

Roga, M., Lubiatowski, P., Lisiewicz, E., Romanowski, L. (2014) ,Analysis of normal glenohumeral joint proprioception". IRONS 5 Sherrington, C. (1906) „The integrative action of the nervous system." New Heaven, CT: Yale University Press.

Talis, V.L., Levik, Y.S. (2011) „Does the stability of elbow support influence the elbow joint matching accuracy?" J Integr Neurosci. 10(2), pp. 177-188.

Tripp, B.L., Faust, D., Jacobs, P. (2009) „Elbow joint position sense after neuromuscular training with handheld vibration." J Athl Train. 44(6), pp. 617-23. 
Authors reported no source of funding. Authors declared no conflict of interest.

Author responsible for correspondence: Ewa Bręborowicz Department of Traumatology, Orthopedics and Hand Surgery

Poznan University of Medical Sciences, Poland ewabreborowicz@gmail.com
Autorzy nie zgłosili źródła finansowania.

Autorzy nie deklarowali konfliktu interesów.

Autor odpowiedzialny za korespondencję: Bręborowicz Ewa

Katedra i Klinika Traumatologii, Ortopedii i Chirurgii Ręki

Uniwersytet Medyczny w Poznaniu ewabreborowicz@gmail.com 